\title{
Nonlethal, attenuated, transfusion-associated graft-versus-host disease in an immunocompromised child: case report and review of the literature
}

\author{
João F. Neves, António Marques, Rosalina Valente, and Deolinda Barata
}

BACKGROUND: Transfusion-associated graft-versushost disease (TA-GVHD) is a rare complication of transfusion of nonirradiated blood components. It usually affects children in high-risk groups, including those who have primary immunodeficiencies (PIDs). It usually presents with skin, hepatic, digestive, and hematologic involvement and is normally fatal.

CASE REPORT: We report the case of a nonlethal, attenuated, TA-GVHD in a 7-month-old boy. The disease was marked by the presence of a severe rash but lacked all the other usual manifestations. We speculate that the unusually benign course of this disease, which has normally a fulminant course, was due to the fact that this child was under high-dose corticotherapy at the time of the engraftment. This fortunate coincidence led to the survival of this child and allowed the diagnosis of a combined immunodeficiency.

CONCLUSION: A high index of suspicion is required for the diagnosis and proper management of PID. The administration of nonirradiated blood components in the first year of life, sometimes before the clinical suspicion of a PID, is of great concern. TA-GVHD may be more prevalent than reported in the literature and it is possibly a nonidentified cause of death in recipients with unexplained death and nondiagnosed PID.
$\mathrm{T}$ ransfusion-associated graft-versus-host disease (TA-GVHD) is a rare complication of blood transfusion. ${ }^{1}$ Its true incidence is not known but it is estimated that it is decreasing with the routine application of the prevention techniques, such as the gamma irradiation of cellular blood products with doses of 25 to 50 Gy for transfusions in recipients belonging to risk groups ${ }^{2}$ and leukoreduction (with much better performance with the recent advances of the filtration technology) of all blood components. ${ }^{3}$ The "threshold" dose of lymphocytes required for TA-GVHD in humans is not known and probably depends on the recipient's ability to reject the transfused lymphocytes. ${ }^{1}$ As little as $3 \times 10^{4} \mathrm{~T}$ lymphocytes is sufficient to cause lethal TA-GVHD in marrow transplant recipients. ${ }^{4}$ It has been stated that gamma irradiation with $25 \mathrm{~Gy}$ is adequate to cause T-cell depletion and prevent T-cell growth. ${ }^{5}$

No cases of TA-GVHD were reported in 2008 in the United Kingdom and there was only one report since the implementation of leukoreduction of all blood components (except granulocytes) in $1999 .{ }^{6}$ Nevertheless,

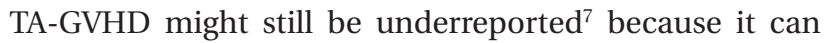
mimic many other conditions, such as viral infections or drug reaction, and it has normally a fulminant course, ${ }^{8}$ thus not permitting a proper diagnosis. Adding to this, the current understanding is that there is growing evidence that supports the possibility of the occurrence of

ABBREVIATIONS: CID = combined immunodeficiency; $\mathrm{PICU}=$ pediatric intensive care unit; $\mathrm{PID}(\mathrm{s})=$ primary immunodeficiency(-ies); TA-GVHD = transfusion-associated graft-versus-host disease.

From the Pediatric Intensive Care Unit, Hospital Dona Estefânia, Lisbon, Portugal.

Address reprint requests to: João Farela Neves, Unidade de Cuidados Intensivos, Hospital Dona Estefânia, Rua Jacinta Marto, 1169-045 Lisbon, Portugal; e-mail: jpfn13@gmail.com. Received for publication January 25, 2010; revision received March 23, 2010, and accepted March 24, 2010. doi: 10.1111/j.1537-2995.2010.02705.x TRANSFUSION 2010;50:2484-2488. 


\begin{tabular}{|lc|}
\hline \multicolumn{2}{|c|}{ TABLE 1. Risk factors for TA-GVHD } \\
\hline Significantly increased risk & No risk \\
\hline Autologous marrow/stem cell transplant recipients & Healthy newborns \\
Allogeneic marrow/stem cell transplant recipients & $\begin{array}{c}\text { Patients with AIDS } \\
\text { Hodgkin's disease }\end{array}$ \\
$\begin{array}{c}\text { Acute leukemia without } \\
\text { transplantation }\end{array}$ \\
B-cell malignancies (non-Hodgkin's lymphoma, \\
multiple myeloma, Waldensrom's macroglobulinemia, \\
ALL) & \\
Fludarabine, cladribine therapy & \\
Granulocyte transfusions in infants & \\
Intrauterine transfusions & \\
Directed donations from blood relatives & \\
HLA-matched platelets & \\
Congenital immunodeficiency disorders & \\
\hline
\end{tabular}

subclinical TA-GVHD, especially among small children and among those who receive cellular transfusions after traumatic injury. ${ }^{9}$

In order that TA-GVHD becomes a reality, as described by Billingham in $1966,{ }^{10}$ several conditions must be observed: 1) immunologic competent lymphocytes must engraft, 2) the host must differ antigenically from the graft, and 3) the recipient must not be able to mount an adequate response against the graft. Because the first two premises are almost universally present, the third is the one that spots the difference and based on it risk groups ${ }^{11}$ were created for the development of TA-GVHD (Table 1). A similar result may be observed when there is a HLA similarity between the donor and the recipient (like in family member donors or in populations that have a high homogeneity in HLA types), even in the absence of immunosuppression as the haploidentical donor lymphocytes may escape the recipient's immune surveillance and attack the recipient's tissues by reacting against HLAs that are not shared. ${ }^{8}$ Newborns are at particular risk of TA-GVHD because they are physiologically immune incompetents and underlying congenital T-cell immunodeficiencies may be yet undiagnosed. It is recommended that all blood for intrauterine transfusions and exchange transfusions should be irradiated. Interestingly, there is no indication for the irradiation of blood for routine transfusions of the term or preterm newborn. ${ }^{1}$

\section{MATERIALS AND METHODS}

\section{Preparation of red blood cells}

Using anticoagulant citrate dextrose, the red blood cells (RBCs) were separated using buffy coat procedure and stored with saline-adenine-glucose-mannitol (376 mOsm/L).

\section{DNA polymorphism analysis}

Evaluation of chimerism was performed on four short-tandem repeats locus (HUMTH01, HUMVwA,
HUMF13A1; HUMFES and a sex marker amelogenin)-specific polymerase chain reaction (PCR) amplification with dye primers. Donor and recipient were characterized and the degree of mixture was evaluated before and after cell separation using a cell sorter (Aria, BD, Franklin Lakes, NJ). DNA was extracted using M48 DNA extraction apparatus (QIAgen, Chatsworth, CA) and shorttandem repeat amplification was performed in each cell subset using the primers mentioned. The degree of chimerism was analyzed after capillary array electrophoresis, in an automatic DNA sequencing machine (Beckman Coulter, Fullerton, CA), with software (CEQ8000, Beckman Coulter), as described elsewhere. ${ }^{12}$

\section{Immunologic testing}

Lymphocyte proliferation responses to phytohemagglutinin, concanavalin A, and pokeweed mitogen were assayed as previously reported. ${ }^{13}$

\section{Review of the literature}

We searched PubMed for articles in English published between 1980 and August 2009 with the following key words in the title: "transfusion-associated graft-versushost." We found 151 articles, some descriptions of nonlethal cases but no case of attenuated TA-GVHD in a child.

\section{CASE REPORT}

A 7-month-old boy with normal development and growth, as well as no known past infections, was admitted in the pediatric intensive care unit (PICU) of a tertiary pediatric hospital in Lisbon for pneumococcal sepsis complicating an adenovirus bronchiolitis. He needed mechanical ventilation for 7 days. On Days 2 and 7, under $4 \mathrm{mg} / \mathrm{kg} /$ day hydrocortisone, he received two transfusions of $10 \mathrm{~mL} / \mathrm{kg}$ leukoreduced, nonirradiated RBCs (aged 0 and 5 days) from the same donor. On Day 14 he started to have fever and developed a generalized rash with coalescent erythematous macules involving palms and soles, treated as toxic reaction to drugs with $3 \mathrm{mg} / \mathrm{kg} /$ day methylprednisolone. All potential drugs involved were discontinued (namely vancomycin and cefotaxime). The child was discharged to the general pediatrics ward on Day 23 where he stayed until Day 40. His stay in the general pediatrics ward was marked by severe dependence on oxygen and worsening of the rash, with areas of erythematous papules and scaling (Fig. 1). On Day 40 he was readmitted in the PICU for severe rash, sepsis, and respiratory failure. At this time, 


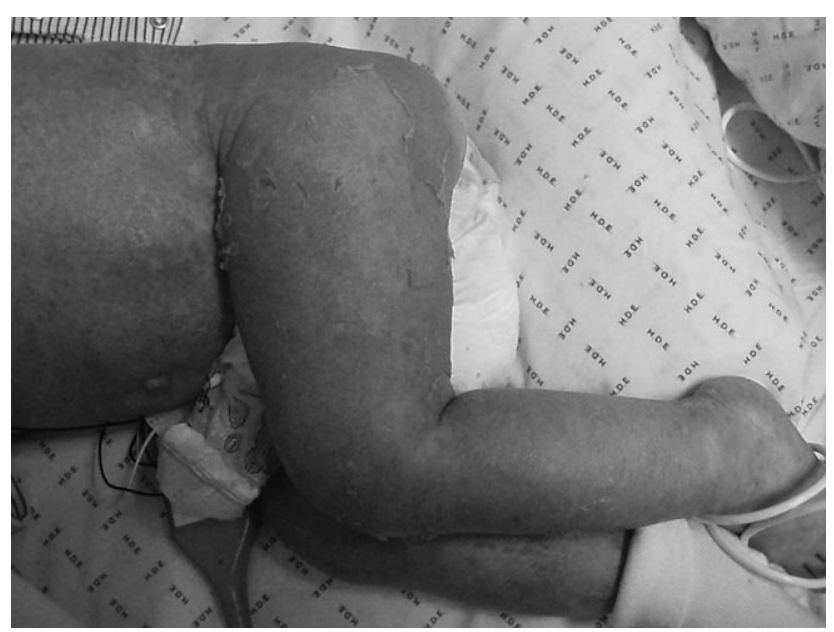

Fig. 1. Skin involvement.

\begin{tabular}{|c|c|c|}
\hline & & \\
\hline \multicolumn{3}{|l|}{ Serum immunoglobulins } \\
\hline $\operatorname{lgG}(\mathrm{mg} / \mathrm{mL})$ & 4.64 & $3.3-6.2$ \\
\hline $\operatorname{lgM}(\mathrm{mg} / \mathrm{mL})$ & 0.38 & $0.2-0.8$ \\
\hline $\lg A(\mathrm{mg} / \mathrm{mL})$ & $<0.2$ & $0.5-1.3$ \\
\hline $\lg E(U / m L)$ & 17 & $<30$ \\
\hline \multicolumn{3}{|l|}{ Vaccine titers } \\
\hline Tetanus (IU/mL) & 0.95 & $>0.15$ \\
\hline Diphtheria (IU/mL) & 0.12 & $>0.15$ \\
\hline Isohemagglutinin titers $\mathrm{A}$ and $\mathrm{B}$ & $<8$ & $>16$ \\
\hline \multicolumn{3}{|l|}{ Lymphocyte subsets } \\
\hline $\mathrm{CD} 3+$ cells $/ \mathrm{uL}$ & 660 & $2156-3413$ \\
\hline CD4+ cells $/ \mu \mathrm{L}$ & 418 & $1360-3066$ \\
\hline CD4CD45RA (\%) & 60 & $75-90$ \\
\hline $\mathrm{CD} 8+$ cells $/ \mu \mathrm{L}$ & 231 & $560-1803$ \\
\hline CD19+ cells/uL & 385 & $811-1792$ \\
\hline CD16+56+ cells/ $\mu \mathrm{L}$ & 55 & $164-801$ \\
\hline \multicolumn{3}{|l|}{ Lymphocyte proliferation (cpm) } \\
\hline Phytohemagglutinin & \multicolumn{2}{|l|}{$3164 \pm 511$} \\
\hline Concanavalin A & \multicolumn{2}{|l|}{$2755 \pm 527$} \\
\hline Pokeweed mitogen & \multicolumn{2}{|l|}{$7890 \pm 358$} \\
\hline V $\beta$ TCR repertoire & \multicolumn{2}{|c|}{ Normal } \\
\hline
\end{tabular}

he was under no medication except prednisolone. Viral PCR and shell viral culture for enterovirus; Epstein-Barr virus; cytomegalovirus; human herpesvirus 6,7 , and 8 ; varicella zoster virus; jc virus; and BK virus were negative. During this admission, according to the history of severe infections caused by both virus and bacteria, a clinical suspicion of combined immunodeficiency (CID) and GVHD was raised. The immunologic panel confirmed the hypothesis of a CID/hypomorphe SCID and the most common genetic defects were ruled out (Table 2).

The child started antibacterial and antifungal prophylaxis, as well as immunoglobulin replacement. Clinically he did very well, apart from two septic events related with the central venous catheter (Staphylococcus aureus and Klebsiella pneumoniae).

The chimerism studies confirmed the presence of exogenous lymphocytes accounting for $16 \%$ of total lym- phocyte count. Maternal engraftment was ruled out and the lymphocytes were shown to belong to the RBC transfusion donor (Fig. 2). This fact along with the clinical manifestations (the characteristic rash but lacking digestive, hepatic, and hematologic involvement) and the skin biopsy (lymphocyte infiltrate with focal parakeratosis and necrosis of the keratinocytes, without eosinophil infiltration) led to the diagnosis of attenuated TA-GVHD. Unfortunately, in situ hybridization of the skin biopsy that could have identified the donor lymphocytes was not performed. He started treatment with cyclosporine (serum levels of 150-250 ng/mL), allowing the weaning of the corticotherapy. There was a slow but progressive clinical improvement with disappearance of the rash along with the disappearance of the chimerism (1 month after the beginning of this therapy the chimerism showed the absence of exogenous lymphocytes). At the age of 14 months he was discharged from the PICU, still under cyclosporine and corticotherapy without any TA-GVHD manifestations.

\section{DISCUSSION AND CONCLUSION}

TA-GVHD is, as stated above, a fatal complication of blood transfusion. Its rarity is probably due to the improvement of the prevention techniques but presumably also to underdiagnosis. ${ }^{7}$ The disease usually presents 4 to 21 days (median, 10 days) after the transfusion of any cellular blood product and has a fulminant course with skin, hepatic, digestive, and hematologic involvement. ${ }^{14}$ The classic symptoms are fever, rash, liver dysfunction, and diarrhea. Most commonly, fever is the first manifestation and it is followed by the appearance of an erythematous, maculopapular skin rash that starts on the trunk and spreads through palms and soles. The degree of liver involvement is variable, as are the gastrointestinal complications. Pancytopenia develops in a median of 16 days and is severe.

The definitive diagnosis of TA-GVHD needs the demonstration of donor-derived cells or DNA fragments in the blood or affected tissues of the recipient. Nevertheless, we underline that the diagnosis of TA-GVHD cannot be based only in the presence of lymphocytes of the blood transfusion donor as there can exist as much as $1 \%$ of subclinical microchimerism. ${ }^{9}$

Although it is rare, we speculate that some cases might be classified as toxic, viral, or autoimmune occurrences with fatal outcome in toddlers. In the United Kingdom 13 cases of TA-GVHD have been reported since 1996 with a mortality of $100 \%{ }^{6}$ To our knowledge, no cases of TA-GVHD have been reported in Portugal since 2000.

Aware of its rarity and knowing the difficulties that diagnosing this condition raise, the authors believe that this child had subclinical TA-GVHD. The diagnosis was based not only on the engraftment of exogenous 


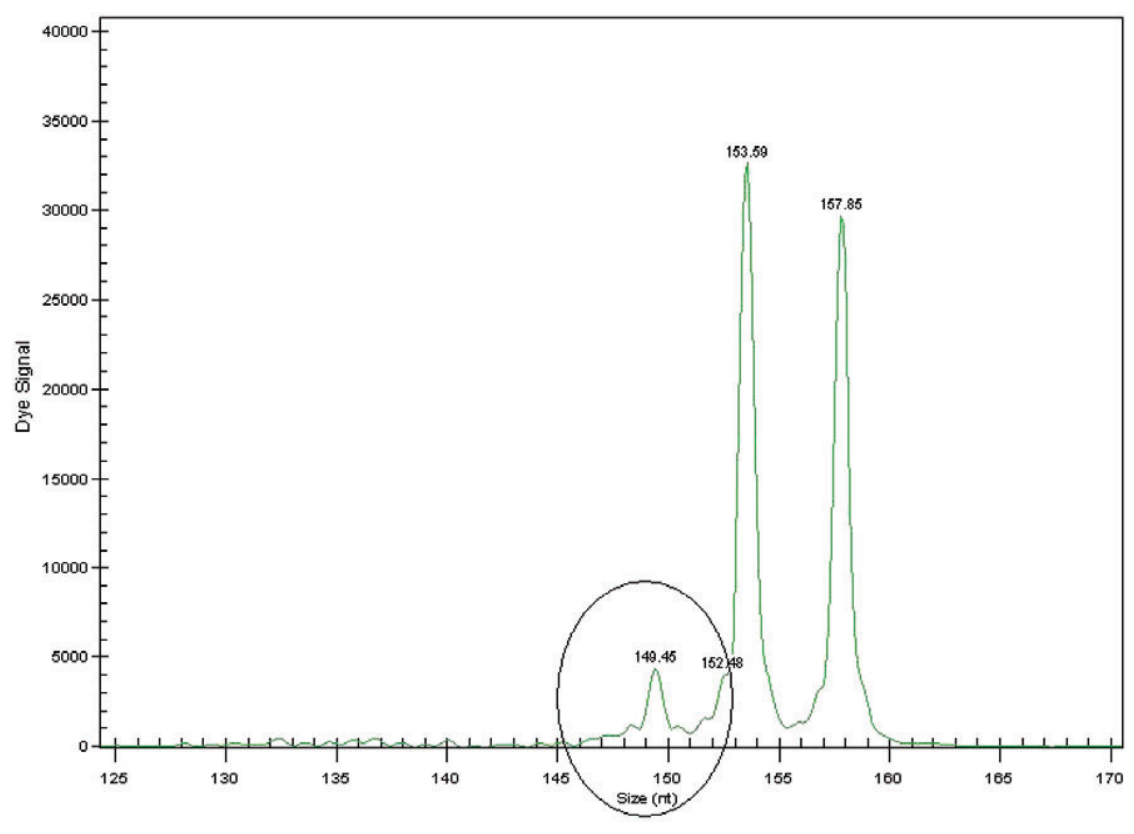

Fig. 2. Chimerism studies.

lymphocytes but also on the fact that the recipient was immunodeficient and had characteristic rash and skin biopsy, ${ }^{15}$ and other causes such as viral infections or drug reaction were ruled out.

The absence of all the other clinical characteristics is extremely infrequent and is possibly linked to the fact that he was receiving high-dose corticotherapy for his respiratory condition. Its mild course permitted the diagnosis of a CID. In pediatric practice, apart from the newborn period and oncology, the most important factor for the presence of TA-GVHD is primary immunodeficiency (PID). Among these, the risk is variable and almost exclusive of the cellular PID. ${ }^{1}$

A high index of suspicion is required for the diagnosis and proper management of PID. The administration of nonirradiated blood components in the first year of life, sometimes before the clinical suspicion of a PID, is of great concern. TA-GVHD is probably more prevalent than reported in the literature and it is possibly a nonidentified cause of death in recipients with unexplained death and nondiagnosed PID.

In countries where the diagnosis of cellular PID (especially severe CID) is well below expected (in conformity with the expected occurrence), the possibility of a fatal outcome due to the transfusion of nonirradiated blood components before the suspicion of cellular PID is a reality. Some institutions have therefore decided to irradiate all blood that is transfused in the first year of life.

\section{ACKNOWLEDGMENTS}

We thank the following for the important technical support: Hospital Dona Estefânia’s Blood Bank; Dr António Martinho and the
Histocompatibility Center Laboratory of Portugal; and Dra. Adriana Albuquerque and the Immunology Laboratory of the Molecular Medicine Institute, Hospital Santa Maria, Lisbon.

\section{CONFLICT OF INTEREST}

The authors declare that they have no conflicts of interest relevant to the manuscript submitted to TRANSFUSION.

\section{REFERENCES}

1. BCSH Blood Transfusion Task Force. Guidelines on gamma irradiation of blood components for the prevention of transfusion-associated graft-versus-host disease. Transfus Med 1996;6:261-71.

2. Landi EP, de Oliveira JS. Transfusion-associated graftversus-host disease guideline on gamma irradiation of blood components. Rev Assoc Med Bras 1999;45: 261-72.

3. Williamson LM, Stainsby D, Jones H, Love E, Chapman CE, Navarrete C, Lucas G, Beatty C, Casbard A, Cohen H. The impact of universal leukodepletion of the blood supply on hemovigilance reports of posttransfusion purpura and transfusion-associated graft-versus-host disease. Transfusion 2007;47:1455-67.

4. Kernan N, Collins N, Juliano L, Cartagena T, Dupont B, Reilly R. Clonable T lymphocytes in T cell-depleted bone marrow transplants correlate with development of graftversus-host disease. Blood 1986;68:770-3.

5. Pelszynski M, Moroff G, Luban N, Taylor B, Quinones R. Effect of gamma irradiation of red blood cell units on T-cell inactivation as assessed by limiting dilution analysis: 
implications for preventing transfusion-associated graftversus-host disease. Blood 1994;83:1683-9.

6. Serious Hazards of Transfusion Steering Committee. Serious hazards of transfusion: annual report 2006 [monograph on the Internet]. Manchester (UK): SHOT Office; 2007. [cited 2009 Dec 20]. Available from: http:// www.shotuk.org/wp-content/uploads/2010/03/SHOTReport-2008.pdf

7. Sanders MR, Graeber JE. Postransfusion graft-versus-host disease in infancy. J Paediatr 1990;117:159-63.

8. Schroeder MD, Marlis L. Transfusion-associated graft-versus-host disease. Br J Haematol 2002;117: 275-87.

9. Utter GH, Reed WF, Lee TH, Busch MP. Transfusionassociated microchimerism. Vox Sang 2007;93:188-95.

10. Billingham RE. The biology of graft-versus-host reactions. New York: Academic Press; 1966. p. 21-78.
11. Rühl H, Bein G, Sachs UJ. Transfusion-associated graftversus-host disease. Transfus Med Rev 2009;23:62-71.

12. Warren LJ, Simmer K, Roxby D, Grist S, Seshadri R, Morley A. DNA polymorphism analysis in transfusion-associated graft-versus-host disease. J Paediatr Child Health 1999;35: 98-101.

13. Stone KD, Feldman HA, Huisman C, Howlett C, Jabara HH, Bonilla FA. Analysis of in vitro lymphocyte proliferation as a screening tool for cellular immunodeficiency. Clin Immunol 2009;131:41-9.

14. Dwyre DM, Holland PV. Transfusion-associated graftversus-host disease. Vox Sang 2008;95:85-93.

15. Denianke KS, Frieden IJ, Cowan MJ, Williams ML, McCalmont TH. Cutaneous manifestations of maternal engraftment in patients with severe combined immunodeficiency: a clinicopathologic study. Bone Marrow Transplant 2001;28:227-33. 